\title{
ECONOMIC ANALYSIS OF SOIL AND ASSOCIATED NUTRIENT LOSS FROM GULLY EROSION FEATURES IN MUBI AREA, ADAMAWA STATE-NIGERIA
}

I. J. TEKWA, O. Y. AMBALI AND Y. A. GARJILA

(Received 15 August 2012; Revision Accepted 10 October 2012)

\begin{abstract}
A study on the economic analysis of soil and associated nutrients conceded to gully erosion at six sublocations within Mubi area, Adamawa state during the 2007 and 2008 wet seasons. Soil and nutrient loss parameters that related to water erosion were studied in the field, alongside determination of some relevant physico-chemical properties in the laboratory. Relative percentages and tables were used to compare the results. The study revealed an alarming estimates of soil mass and associated nutrient loss in both study years. Economic implications appeared disturbing and demands an immediate attention in order to curtail further uncertainties of unbearable colossal soil and nutrient losses, except otherwise managed using suggested conservation measures that could compatibly obliterate the menace in the study area.
\end{abstract}

KEY WORDS: Economic analysis, Soil loss, Nutrient loss, Equivalent weights, Gully erosion, Nigeria.

\section{INTRODUCTION}

Gully erosion perhaps constitute one of the severe land management problem confronting man and his ecosystem since the prehistoric time of global land use. It is a devastating phenomenon that transforms soil into sediments thereby resulting into the loss of soil and its associated plant nutrients. According to Reij et al (1996) and Brady and Weil (2002), the impact of gully erosion on soil physico-chemical properties are often reflected in terms of retarded agronomical potentials, degraded plant and animal ecosystems as well as environmental pollution which often translates into loss of life and property. Other visually impressive consequences include: reduction in land productivity potentials, destruction of farm and housing structures as much as obstruction to farm roads and other means of farm transportation (Morgan, 1996, Lal, 1995).

The incidence of gully erosion in northern Nigeria, especially the north-eastern region, has attained a higher state of devastation and may probably be attributed to artificially formed gully features from excessive land usage beyond threshold limits (Lal, 1976). In the reports of Ekwue and Aliyu (1990), Over 1000 tones of soil were annually conceded to gully erosion in Biu local government area of Borno state. Similarly, in Sade town of Bauchi state, about 31,000 tones of soil was reportedly lost to gully erosion (Ekwu and Tashiwa, 1992).

Generally, the economics of gully erosion reclamation has always been a function of comparative judgment on cost implications and potential benefits for reclaiming particular gully erosion. This is simply because the control of gully erosion is expensive and difficult and has no existing precise data (Hudson, 1989 and Brady, 1988). However, regional average costs are normally employed to estimate the cost implication of controlling erosion in any location within a given region. In Nigeria, Lal (1977) reported that a soil loss of over 13 million tones estimated at N3000 million occurs annually at Shandam and western Pankshim areas of Plateau state.

In Mubi area, attention in the past were only focused on the prevalence and primary control measures of gully erosion using check dams, tree planting as well as construction of local embankment with sand bags and stone barriers. At present, dearth information on the economic implications of soil and nutrient loss and their eroded land sizes exist, except for the estimation of soil and nutrient loss from gully erosion features earlier reported by Tekwa et al, (2006) for the same environment. It is against this background that this study is set out to carry out an economic analysis of both soil and nutrient loss from gully erosion features in the study area.

\section{MATERIAL AND METHODS}

\section{The Study Area}

Mubi area is situated in the north eastern part of Adamawa state and located between latitudes $9^{\circ} 26^{\prime \prime}$ and $10^{\circ} 11^{\prime \prime} \mathrm{N}$ and between longitudes $13^{\circ} 1$ " and $13^{\circ} 44^{\prime \prime} \mathrm{E}$. It has a land area of $506.40 \mathrm{~km}^{2}$ and a population size of 759,045 , with a density of 160.5 people per square kilometer (Nwogboso and Uyanda 1999). The local government shares boundaries with Michika to the North, Askira-Uba to the West, and Hong local government to the South. It also shares international boundary with the Republic of Cameroon to the East. 
The climate of the area is characterized by alternating dry and wet seasons. The rain lasts from April to October with a mean annual rainfall ranging from 700 $\mathrm{mm}$ to $1,050 \mathrm{~mm}$ (Udo, 1970; Adebayo, 2004). The vegetation is of typical Sudan Savannah, which implies grassland interposed by shrubs and few trees mostly, acacia, eucalyptus and locust-bean trees among others (Adebayo, 2004; Tekwa and Usman, 2006). The dominant physical feature in the area is the Mandara Mountain ranges which initiate run-off generation that are largely facilitated by the area's undulating topography. The land use types are mainly arable farming and livestock production threatened by soil erosion at varying devastations, from sheet and rill erosion to the spectacular gully erosion known for colossal loss of soil and soil nutrients (Tekwa et al 2006).

\section{Field Study}

Six villages, namely: Vimtim, Digil, Muvur, Gella, Lamorde and Madanya villages were surveyed in this study. The villages were purposively sampled on the basis of their prominence as the major gully affected areas in Mubi (Tekwa and Usman, 2006). Two composite soil samples were collected using soil auger from each study site in well labeled polythene bags, then dried, crushed and sieved through a $2 \mathrm{~mm}$ sieve and kept for routine laboratory determination of the soil physico-chemical properties. Data on total soil loss in each gully site were collected by measuring the length (I), width (w) and depth (h) of the gully channels at $30 \mathrm{~m}$ intervals along the gully surface (Ekwue and Tashiwa, 1992; Tekwa and Usman, 2006).

\section{Determination of Soil Properties}

The soil particle size distribution was determined using the Bouyoucus Hydrometer method (Trout et al, 1987). Soil organic carbon content was determined by Walkley and Black (1934) method. Total Nitrogen $(\mathrm{N})$ was determined by Kjeldahl digestion method (Bremner and Mulvaney, 1982), while available Phosphorus $(P)$ by Bray method (Bray and Kurz, 1985), Potassium and Sodium were determined by flame photometry (Pag, et al., 1982). Exchangeable $\mathrm{Ca}^{+}$and $\mathrm{Mg}^{2+}$ were determined by titrimetric method, while Cation Exchange Capacity (CEC) and Total Exchangeable Bases (TEB) were computed from the results.

\section{Estimation of Soil and Nutrient loss}

Soil loss estimates was determined using channel geometry (Duncan, et al., 1978) as presented in Appendix 2. The soil nutrient loss estimates were computed based on the methods described by Nandwa (2003). The elemental losses were estimated for the three major soil nutrient elements (Nitrogen, Phosphorus and Potassium), following the procedures outlined in Appendix 3.

The estimated nutrients lost were presented in equivalents of $50 \mathrm{~kg}$ fertilizer bags, with the aim of determining the financial cost involved. Likewise, the total cost of soil loss was obtained by converting the total weights of soil loss into an equivalent weight of a
Tipper load (TL) of soil and financially quantified based on the prevailing market prices during the study period (Appendix 2). The data collected was analyzed using simple percentages and tables to compare the results.

\section{RESULTS AND DISCUSSION}

\section{Estimated Area of Soil loss}

The average area of soil loss estimated in all the locations ranged between $254.02 \mathrm{~m}^{2}$ and $673.34 \mathrm{~m}^{2}$ in 2007 , and with a similar range of between $238.00 \mathrm{~m}^{2}$ and $688.31 \mathrm{~m}^{2}$ in 2008 (Table 1). In 2007, it was observed that Lamorde $\left(673.34 \mathrm{~m}^{2}\right)$ recorded the largest area of soil loss. The soil loss estimated at other locations followed in the sequence: Muvur $\left(565.70 \mathrm{~m}^{2}\right)$, Digil $\left(490.98 \mathrm{~m}^{2}\right)$, Gella $\left(357.44 \mathrm{~m}^{2}\right)$, and Madanya $\left(335.80 \mathrm{~m}^{2}\right)$, while the least area of loss was that of Vimtim $\left(254.02 \mathrm{~m}^{2}\right)$ location. The observed low erosion rates was perhaps due to the impact of concreted clay fractions at greater soil depths that bound the soil aggregates against excessive erosion losses during the study period. This claim agrees with previous reports on the relevance of high clay activity during water erosion (Capra et al., 2004; Woodward, 1999; Foster, 1986).

In 2008, it was similarly observed that Lamorde $\left(688.32 \mathrm{~m}^{2}\right)$ remained the location with the largest area of soil loss and was still followed by Muvur location $\left(586.45 \mathrm{~m}^{2}\right)$ as it was the case in 2007 . The soil loss magnitude observed at Lamorde in 2008, was respectively about twice and thrice the amounts recorded at Madanya and Vimtim locations in 2007 (Table 1). This event was likely due to the higher rainfall received in addition to the observed high sand and silt aggregations that formed the soils (Appendix 1), which progressively eroded between study years. The third largest area of soil loss was at Madanya location $\left(518.10 \mathrm{~m}^{2}\right)$, followed by Digil $\left(377.50 \mathrm{~m}^{2}\right)$, Vimtim $\left(362.56 \mathrm{~m}^{2}\right)$, and the least loss was recorded at Gella $\left(238.00 \mathrm{~m}^{2}\right)$ location. In all the location, a total area of soil loss of $2677.28 \mathrm{~m}^{2}$ and $2770.93 \mathrm{~m}^{2}$ with a grand mean of $446.21 \mathrm{~m}^{2}$ and $461.82 \mathrm{~m}^{2}$ were recorded in 2007 and 2008 respectively. The soil loss rate increased between study years and implied that there existed no effective control measures in place to have curtailed erosion progress in the study area. Compatible conservation measures such as agronomic practices alongside physical structures needs to be applied at a minimum cost in order to halt erosion menace as previously advocated by Tekwa and Usman (2006), Tekwa et al (2006), and Ekwue and Tashiwa (1992) for the same region.

\section{Estimated Weights of soil loss}

As shown in Table 1, result for 2007 revealed that the estimated weight of soil loss in all the locations ranged between $159574.14 \mathrm{~kg} / \mathrm{ha}$ and $725345.01 \mathrm{~kg} / \mathrm{ha}$. Muvur location recorded the largest weights (725345.14kg/ha), accounting for about $33 \%$ of the total soil loss, followed by Lomorde $(589619.5 \mathrm{~kg} / \mathrm{ha})$, then Digil (404321.63kg/ha) and Mandanya (211619.27kg/ha), representing 26, 18 and $9 \%$ of the estimated total soil loss figure, respectively. Vimtim recorded the least quantity of $159574.14 \mathrm{~kg}$ of soil lost to gully erosion, 
Table 1: Soil loss estimates and relative percentages

\begin{tabular}{lrrrrrr}
\hline \multicolumn{1}{c}{ Location } & \multicolumn{2}{c}{ Area of soil loss $\mathbf{( m}^{2} \mathbf{l}$} & \multicolumn{2}{c}{ Weight of soil loss $\mathbf{( k g} / \mathbf{h a})$} & \multicolumn{2}{c}{ Percent soil loss } \\
& $\mathbf{2 0 0 7}$ & $\mathbf{2 0 0 8}$ & $\mathbf{2 0 0 7}$ & $\mathbf{2 0 0 8}$ & $\mathbf{2 0 0 7}$ & $\mathbf{2 0 0 8}$ \\
\hline Digil & 490.98 & 377.50 & 404321.63 & 293185.65 & 18 & 10 \\
Muvur & 565.70 & 586.45 & 725345.01 & 984400.56 & 33 & 35 \\
Vimtim & 254.02 & 362.56 & 159574.14 & 296688.60 & 7 & 11 \\
Gella & 357.44 & 238.00 & 161257.14 & 101556.00 & 7 & 4 \\
Lamorde & 673.34 & 688.32 & 589619.57 & 620089.74 & 26 & 22 \\
Madanya & 335.80 & 518.10 & 211619.27 & 491007.60 & 9 & 18 \\
Total & $\mathbf{2 6 7 7 . 2 8}$ & $\mathbf{2 7 7 0 . 9 3}$ & $\mathbf{2 2 5 1 7 3 6 . 7 6}$ & $\mathbf{2 7 8 6 9 2 8 . 1 5}$ & $\mathbf{1 0 0}$ & $\mathbf{1 0 0}$ \\
Mean & $\mathbf{4 4 6 . 2 1}$ & $\mathbf{4 6 1 . 8 2}$ & $\mathbf{3 7 5 , 2 8 9 . 4 6}$ & $\mathbf{4 6 4 , 4 8 8 . 0 3}$ & & \\
\hline
\end{tabular}

Table 2: Soil loss and Cost estimates

\begin{tabular}{lcccccc}
\hline Location & \multicolumn{2}{c}{ Weight of soil loss $\mathbf{( k g / h a )}$} & \multicolumn{2}{c}{ Equivalent number of } & \multicolumn{2}{c}{$\begin{array}{c}\text { Estimated cost of } \\
\text { soil loss (N) }\end{array}$} \\
& $\mathbf{2 0 0 7}$ & $\mathbf{2 0 0 8}$ & $\mathbf{2 0 0 7}$ & $\mathbf{2 0 0 8}$ & $\mathbf{2 0 0 7}$ & $\mathbf{2 0 0 8}$ \\
\hline Digil & 404321.63 & 293185.65 & 66 & 39 & 198000 & 117000 \\
Muvur & 725345.01 & 984400.56 & 178 & 160 & 534000 & 480000 \\
Vimtim & 159574.14 & 296688.60 & 26 & 48 & 78000 & 144000 \\
Gella & 161257.14 & 101556.00 & 26 & 17 & 78000 & 51000 \\
Lamorde & 589619.57 & 620089.74 & 96 & 101 & 288000 & 303000 \\
Madanya & 211619.27 & 491007.60 & 34 & 80 & 102000 & 240000 \\
Total & 2251736.76 & 2786928.15 & 426 & 445 & 1278000 & 1335000 \\
Mean & $\mathbf{3 7 5 , 2 8 9 . 4 6}$ & $\mathbf{4 6 4 , 4 8 8 . 0 3}$ & $\mathbf{7 1}$ & $\mathbf{7 4 . 1 7}$ & $\mathbf{2 1 3 , 0 0 0}$ & $\mathbf{2 2 2 , 5 0 0}$ \\
\hline
\end{tabular}

Key: $\quad$ 1. Equivalent weight of Tipper load $(\mathrm{T} 56 \mathrm{~T})=6160 \mathrm{~kg}$

2. Unit cost of a Tipper load $(6160 \mathrm{~kg})=\mathrm{N} 3000$ in 2007 and 2008 . 
Table 3: Nutrient loss and cost estimates

\begin{tabular}{|c|c|c|c|c|c|c|c|c|c|c|c|c|c|c|}
\hline \multirow[t]{2}{*}{$\begin{array}{l}\text { Study } \\
\text { Location }\end{array}$} & \multirow[t]{2}{*}{$\begin{array}{l}\text { Weight of } \\
\text { soil loss (kg) }\end{array}$} & \multicolumn{3}{|c|}{ Soil Analytical Data } & \multicolumn{3}{|c|}{ Weight of nutrient loss } & \multicolumn{3}{|c|}{$\begin{array}{l}\text { Equivalent number of } \\
\text { fertilizer bags }(50 \mathrm{~kg})\end{array}$} & \multicolumn{3}{|c|}{$\begin{array}{l}\text { Estimated cost of } \\
\text { nutrient loss }\end{array}$} & \multirow{2}{*}{$\begin{array}{l}\text { Total cost } \\
\text { of nutrient } \\
\text { loss } \\
\text { (A) }\end{array}$} \\
\hline & & $\begin{array}{l}\mathrm{N} \\
(\%)\end{array}$ & $\begin{array}{c}\mathrm{P} \\
(\mathrm{ppm})\end{array}$ & $\begin{array}{c}\mathrm{K} \\
(\mathrm{Cmol}(+) \\
/ \mathrm{kg})\end{array}$ & $\mathrm{N}$ & $\begin{array}{l}\mathrm{P}_{2} \mathrm{O}_{5} \\
(\mathrm{~kg})\end{array}$ & $\mathrm{K}_{2} \mathrm{O}$ & $\begin{array}{c}\mathrm{N} \\
\text { (Urea) }\end{array}$ & $\begin{array}{c}P \\
(S S P)\end{array}$ & $\begin{array}{c}\mathrm{K} \\
(\mathrm{MOP})\end{array}$ & $\mathrm{N}$ & $\begin{array}{l}P \\
(A)\end{array}$ & $\mathrm{K}$ & \\
\hline \multicolumn{15}{|c|}{2007} \\
\hline Digil & 404321.63 & 0.17 & 17.68 & 4.58 & 687.35 & 16.37 & 866.64 & 30.0 & 2.0 & 29.0 & 75000 & 4000 & 58000 & 137000.00 \\
\hline Muvur & 725345.01 & 0.27 & 20.88 & 3.47 & 1958.43 & 34.58 & 1177.93 & 85.0 & 4.0 & 39.0 & 212500 & 8000 & 78000 & 298500.00 \\
\hline Vimtim & 159574.14 & 0.14 & 14.33 & 4.23 & 223.40 & 5.24 & 315.90 & 10.0 & 1.0 & 10.5 & 25000 & 2000 & 21000 & 48000.00 \\
\hline Gella & 161257.14 & 0.15 & 22.65 & 1.36 & 241.89 & 8.36 & 102.64 & 10.5 & 1.0 & 3.5 & 26250 & 2000 & 7000 & 35250.00 \\
\hline Lamorde & 589619.57 & 0.17 & 25.88 & 2.03 & 1002.35 & 34.95 & 560.16 & 43.5 & 4.0 & 19.0 & 108750 & 8000 & 38000 & 154750.00 \\
\hline Madanya & 211619.27 & 0.16 & 20.15 & 3.20 & 338.59 & 9.76 & 316.92 & 15.0 & 1.0 & 10.0 & 37500 & 2000 & 20000 & 59500.00 \\
\hline Total & 2251736.76 & 1.06 & 121.57 & 18.87 & 4452.01 & 109.26 & 3340.19 & 194.0 & 13.0 & 111.0 & 485000 & 26000 & 222000 & 733000.00 \\
\hline Mean & 375289.46 & 0.18 & 20.26 & 3.15 & 742.00 & 18.21 & 556.70 & 32.33 & 2.17 & 18.5 & 80833.33 & 4333.33 & 37000.00 & 122166.66 \\
\hline \multicolumn{15}{|c|}{2008} \\
\hline Digil & 293185.65 & 0.19 & 17.95 & 4.84 & 557.05 & 12.05 & 664.10 & 24.0 & 1.5 & 22.0 & 60000 & 3000 & 44000 & 107000.00 \\
\hline Muvur & 984400.56 & 0.21 & 21.00 & 3.85 & 2067.24 & 47.33 & 1773.69 & 90.0 & 5.0 & 59.0 & 225000 & 10000 & 118000 & 353000.00 \\
\hline Vimtim & 296688.60 & 0.15 & 35.03 & 4.45 & 445.03 & 23.79 & 617.88 & 19.0 & 3.0 & 20.5 & 47000 & 6000 & 41000 & 94500.00 \\
\hline Gella & 101566.00 & 0.11 & 23.17 & 1.51 & 111.71 & 5.38 & 71.77 & 5.0 & 1.0 & 2.0 & 12500 & 2000 & 4000 & 18500.00 \\
\hline Lamorde & 620089.74 & 0.20 & 26.34 & 2.09 & 1240.18 & 37.40 & 606.53 & 54.0 & 4.0 & 20.0 & 135000 & 8000 & 40000 & 183000.00 \\
\hline Madanya & 491007.60 & 0.17 & 20.42 & 3.38 & 834.71 & 22.97 & 776.70 & 36.0 & 2.5 & 26.0 & 90000 & 5000 & 52000 & 147000.00 \\
\hline Total & 2786928.15 & 1.03 & 143.91 & 20.12 & 5255.92 & 148.92 & 4510.68 & 228.0 & 17.0 & 149.5 & 569500 & 34000 & 299000 & 903000.00 \\
\hline Mean & $464,488.02$ & 0.17 & 23.99 & 3.35 & 875.99 & 24.82 & 751.78 & 38.0 & 2.83 & 24.92 & 94916.67 & 5666.67 & 49833.33 & 150500.00 \\
\hline
\end{tabular}

Note: 1. Conversion factor of $\mathrm{P}(\mathrm{kg})$ into $\mathrm{P}_{2} \mathrm{O}_{5}=2.29$ and $\mathrm{K}(\mathrm{kg})$ into $\mathrm{K}_{2} \mathrm{O}=1.20$

2. A bag of Urea fertilizer in 2007 cost N2,500.00

A bag of Single Super Phosphate (SSP) fertilizer in 2007 costs N2000

A bag of Murate Of Potash (MOP) fertilizer in 2007 cost N2000.00 
which constituted only $7 \%$ of the total soil loss figure. The relatively high percentage soil losses estimated at both Muvur and Lamorde locations sends a strong signal for urgent conservation inputs, ranging from use of vegetative barriers, sand bag lines and check dams as may be applicable in order to combat further erosion progress. Foster (1986) and Capra et al (2004) reported similar applications of agronomic measures on water erosion advances.

Similarly in 2008 , both Muvur $(984400.56 \mathrm{~kg} / \mathrm{ha})$ and Lamorde $(6210089.27 \mathrm{~kg} / \mathrm{ha})$ locations maintained their leads in terms of soil weight losses and constituted up to 35 and $22 \%$ of the total soil loss, respectively. The percentage soil loss weights were rather high in this study and the trend appeared to reflect the magnitudes of the respective areas of soil loss earlier noted during the study. This soil loss was sequentially followed by Madanya $(491007.60 \mathrm{~kg} / \mathrm{ha})$, Vimtim $(296688.60 \mathrm{~kg} / \mathrm{ha})$, Digil $(293185.65 \mathrm{~kg} / \mathrm{ha})$ and Gella $(101556.00 \mathrm{~kg} / \mathrm{ha})$ with percentages of $18,11,10$, and $4 \%$ respectively. A grand total weight of $2251736.76 \mathrm{~kg} / \mathrm{ha}$ and $2786928.15 \mathrm{~kg} / \mathrm{ha}$ with a mean of $375,289.46 \mathrm{~kg} / \mathrm{ha}$ and 464,4

$88.03 \mathrm{~kg} / \mathrm{ha}$ was gullied in 2007 and 2008 respectively. This range however, compared lower than the earlier estimate of $1000 \mathrm{t} / \mathrm{ha}$ of soil loss recorded from gully features at Biu, Borno state (Ekwue and Aliyu, 1989). This variation was probably due to differences in channel properties, soil behavior and land-use practices.

\section{Estimated cost of soil loss}

The result on the estimated cost of soil loss is presented in Table 2, which showed the amount of soil losses expressed in equivalent number of Tipper load (TL) of soil with their respective monetary values. In 2007 , the number of TLs of soil loss in the locations varied between 26 and 178 with the corresponding cost estimate ranging between $\mathrm{N} 78000$ and N534000. In liked manner, Muvur which had the lead in soil loss magnitude also recorded the highest equivalent number (178) of TL, amounting to a total cost estimate of N534000, while the least estimate (26) of TLs was observed at Vimtim and Gella locations, which tied with an equivalent cost of $\mathrm{N78000}$. In total, about 426 TLs of soil loss that worth $\$ 1,278,000.00$ was recorded in 2007. This estimated amount was rather quite unbearable to the peasant farmers from whose farms such soil losses were evaluated. This menace have perhaps periodically affected the levels of crop returns evident in the study area (Tekwa and Usman, 2006).

In 2008, a relatively higher trend was observed. Muvur recorded 160 TLs of soil loss with cost estimate of N480000. In sequence, Lamorde (101 TL), Madanya (80 TL), Vimtim (48 TL), Digil (39 TL) and Gella (17 TL) with respective cost estimate of $\mathrm{N} 303000$, N240000, $\mathrm{N} 144000, \mathrm{~N} 117000$ and $\mathrm{N} 51000$ were recorded. A total of 445 TLs was gullied in 2008 amounting to about $\mathbf{N}$ $1,335,000.00$ incurred across the study locations. The soil loss cost observed in this study still compared far below the earlier estimate of about $\mathrm{N} 3000$ million incurred annually at Shandam and Western Pankshin areas of Plateau state-Nigeria (Lal, 1977), and was still far below the on-site erosion cost of between $\$ 4$ and $\$ 27$ billion incurred annually across America (Brady,
1988, 2002). The lower erosion cost recorded in this study was perhaps due to the extent of erosion survey carried out on a smaller and fewer erosion features than those assessed previously.

\section{Estimated cost of Nutrient loss}

The economic loss of individual soil nutrient $(\mathrm{N}$, $P$ and K) for 2007 is presented in Table 3. The result accounted $P$ as low cost ranging (N2000 each at Vimtim, Gella and Madanya to N8000 at Muvur and Lamorde), compared to $\mathrm{N}$ which had the largest cost range of between N25000 (in Vimtim) and N212500 (in Muvur). Even though the estimated $\mathrm{P}$ cost was relatively lower than $\mathrm{N}$ and $\mathrm{K}$, but still compared higher than an estimate of $75 \mathrm{~kg} \mathrm{P} / \mathrm{ha}$ amounting to only $N 3000$ reported by Sanchez et al (1982). The $N$ cost range observed in this study compared higher than the earlier estimate of $660 \mathrm{~kg} \mathrm{~N} / \mathrm{ha}$ with an equivalent cost of $\mathrm{N}$ 33,000 estimated on smallholder farms in Kenya (Gichuru et al., 2003). In this study, K losses were moderate, with an equivalent economic loss range of N20000 (in Madanya) to N78000 (in Muvur). Likewise, this cost range however, compared far above the earlier estimate of $450 \mathrm{~kg} \mathrm{~K} / \mathrm{ha}$ equivalent to $\mathrm{N} 18,000$ earlier reported by Sanchez et al (1982).

Likewise, a similar pattern featured in 2008, where the cost estimates resulting from the individual nutrient losses still accounted $P$ as the least estimated nutrient loss with as low as N2000 loss in Gella to as high as N110000 in Muvur. This cost range was over 13 times higher than in 2007. This drastic rise in $\mathrm{P}$ loss costed in 2008 was probably due to increased deposition and application of $P$ fertilizers during the year (Brady and Weils, 2002). Also, as it was the case in 2007, N cost estimates still stood tall with a cost range of between N12500 (in Gella) and to as high as $\mathrm{N} 225000$ (in Muvur). The $\mathrm{K}$ loss estimates remained within the moderate cost range of between N4000 (in Gella) and N118000 (in Muvur) in same year. In a nutshell, all other locations recorded differing loss estimates that featured within the cost ranges observed during this study (Table 3 ). The cost range observed in 2008 appeared similar to those recorded in 2007. However, the cost range for $\mathrm{K}$ was almost doubled in 2008 as earlier presented in Tables 3.

On the overall, total estimates of the nutrient losses costed across all locations ranged between N35250 and N298500 in 2007 and between N18500 and 353000 in 2008. In 2007, Muvur experienced the highest nutrient loss cost of about N298500, followed by Lamorde (N154750), Digil (N137000), Madanya (N59500), Vimtim (N48000) and Gella (N35250).

Similarly in 2008, Muvur still retained its lead in nutrient loss estimates that worth about N353000. The total estimate of nutrient losses in other locations followed in the order: Lamorde (N183000), Madanya (N147000), Digil (N107000), Vimtim (N94500) and the least was at Gella (N18500). In general, the highest total cost estimate (N903000) of nutrient loss was observed in 2008 compared to its lower estimates (N733000) earlier recorded in 2007. It was observed that all the parameters studied corresponded directly with the initial 
area and weights of soil conceded to gully erosion during the study period.

\section{CONCLUSION}

It suffices to conclude that the gradually noticed soil and associated nutrient losses were higher than could be imagined. To most farm owners, both the soil and nutrient loss were rather negligible, except otherwise when investigated and translated quantitatively. The respective soil loss range (26-178 and 17-160 TLs $(6160 \mathrm{~kg})$ ) and cost implications (N78000-N534000 and N51000-N480000) in 2007 and 2008 was high, compared to estimates (31,000 tons of soil mass) reported by Ekwue and Aliyu (1990). Conversely, nutrient loss in terms of $\mathrm{N}, \mathrm{P}$ and $\mathrm{K}$ averaged $32.33,2.17$ and $18.5 \mathrm{~kg}$, respectively, which implied a gross cost range of N48000-N298500 and N18500-353000 in 2007 and 2008, was unimaginably high. These loss estimates were direct functions of soil type and gully properties in terms of length, depth and widths that defined the soil voiding processes. Wise implementation of compatible conservation practice(s) could be very rewarding as previously advocated in similar research works (EKwue and Tashiwa, 1992; Ekwue and Aliyu, 1990).

\section{RECOMMENDATIONS}

It is recommended that farmer awareness on the gross dangers of this gradual, but severe soil and associated nutrient losses during gully erosion processes be advocated by all relevant bodies including both governmental and non governmental agencies. Hence, the need for wider farm visitations towards practicable on-farm erosion control skills for target farmers to embrace the culture of compatible land use practices that maintains soil qualities.

In addition, the nation wide farming skills acquisition centers spread across most states such as Adamawa state, should incorporate soil erosion management as an educational curriculum in their training schemes towards achieving wider application of result oriented erosion control strategies across the Country.

\section{REFERENCES}

Adebayo, A. A., 2004. Mubi Region: A geographical Synthesis. ( $1^{\text {st }}$ Eds.). Paraclete Publishers, Yola-Nigeria. Pp 32-38.

Brady, N. C., 1988. The Nature and Properties of Soil. $\left(9^{\text {th }}\right.$ Ed.) New York Macmillan.

Brady, N. C. and Weil, R. R., 2002. The Nature and Properties of Soils $\left(13^{\text {th }}\right.$ Eds). Pearson Education (Singapore), New Delhi, India.

Bray, R. H. and Kurtz, L. T., 1985. Determination of Total, Organic and Available forms of phosphorus in soils. In: Page, A.L. Miller, R. H. and Keeney, D. R. (1987), Methods of Soil Analysis, Part 2. American Society of Agronomy. Madison, Wisconsin, U.S.A.
Bremner, J. M. and Mulvaney, C, S., 1982. Total Nitrogen. In: Page A.L. Miller, R.H. and Keeney, D.R (1987), Methods of Soil Analysis, Part 2. American Society of Agronomy. Madison, Wisconsin, U.S.A.

Bryan, R. B., 1979. The influence of slope angle on soil detachment by Sheetwash and Rainsplash. Earth Surface Processes, 4:43-58.

Capra, A., L. M. Mazzara and B. Scicolone., 2004. Application of the ephemeral gully erosion model to predict ephemeral gully erosion in Sicily, Italy. ELsveir. Catena. Vol. 59 No.2. pp 113.

Duncan, E. R., W. G. Quas, W.L. Cole, M. A. H. Haubner and T. M., 1978. Sparks. Mathematics. Honghton Mifflin Company. Boston. pp 180-185.

Ekwue, E. I, and H. D. Aliyu., 1990. Survey of Soil Erosion Features in Biu, Borno State. A detailed of former Biu L.G.A. Annals of Borno. 6/7:221230.

Ekwue, E. I. and Tashiwa, Y. I., 1992. Survey of gully erosion features in Mubi local government area of Adamawa State. Annals of Borno. 8/9:181191.

Foster, G. R., 1986. Understanding ephemeral gully erosion. Soil Conservation: Assessing the National Research Inventory, National Research Council, Board on Agriculture 2. National Academy Press. Washington D.C. pp. 90-118.

Gichuru, M. P., A. Bationo, M. A. Bakunda, H. C. Goma, P. L., Mafongonya, D. N. Mugendi, H. M. Murwira, S. M. Nandwa, P. Nyathi and M. J. Swift., 2003. Soil fertility Management in Africa: A Regional Perspective. Academy Science Publishers. Nairobi, Kenya.

Hudson, N. W., 1989. Soil Conservation. B. T. Batsford limited, London.

Lal, R., 1976. Soil Erosion Problems on an Alfisol in Western Nigeria and their Control, IITA Monograph No.1.

Lal, R., 1977. Soil Management Systems and Erosion Control. In: D.J. Greenland, and R. Lal (eds). Soil Conservation and Management in the Humid Tropics. Chichester, Wiley. 93-7.

Lal, R., 1995. "Erosion-Crop Productivity Relationships for the soils of Africa." Soil Science Society of America Journal. 59:661-667.

Morgan, R. P. C., 1996. Soil Erosion and Conservation. $\left(2^{\text {nd }} \mathrm{Ed},\right)$, Longman. London pps. 40-93,

Nandwa, S. M., 2003. Perspective on Soil Fertility in Africa. In: Gchuru et al. (eds), Soil fertility 
management in Africa: A Regional Perspective. Academic Science Publishers Kenya.

Nwagboso, N. K. and Uyanga, J., 1999. Population. In: Adebayo, A.A and A. L. Tukur (eds). Adamawa State in Maps. Department od Geography, F.U.T Yola. Pp92.

Page AL, RH Miller and DR Keeney (1982). Methods of soil Analysis, part 2, Agronomy No. 9, American Society of Agronomy, Madison, Wisconsin, USA.

Reij, C., Scoones, I. and Toulmin, C., 1996. Sustaining the soil: Indigenous soil and water conservation in Africa. U. K. Earthscan Publications Ltd. p. 191-201.

Sanchez PA, Bandy, D. E. and Villchica, J. H., 1982. Amazon Basin Soils: Management for continuous crop production. Science. 216: 821827.

Tekwa, I. J. and Usman, B. H., 2006. Estimation of soil loss by gully erosion in Mubi, Adamawa State, Nigeria. Journal of the Environment. Vol.1 No.1. Paraclete publishers. Yola. Pp 35-43.
Tekwa, I. J., Usman, B. H. and Ibrahim, A., 2006. Estimation of soil nutrient loss by gully erosion and its economic implications in Mubi L.G.A, Nigeria. Journal of Environmental Sciences. Vol.10 (2). Hilgad Press, Jos, Nigeria, Pp 1- 12.

Trout, T. J. M Garcia-Castillas, I. G and Hart, W. E., 1987. Soil Water Engineering: Field and Laboratory Manual. Eusaria. New Delhi India.

Udo, R. K., 1970. Geographical Regions of Nigeria ( $1^{\text {st }}$ Eds.), Pp 195-197. Heinemann. London.

Walkley, A, and Black, C., 1934. An Examination of Destjareff method for determing soil organic matter with Chromic-Acid Titration Method. Soil Science of America Journal. 37:29-38.

Woodward, D. E., 1999. Method to predict cropland ephemeral gully erosion. Catena. 37. pp 393399. 
Appendix 1: Physico-chemical characteristics of soils of the study area

\begin{tabular}{|c|c|c|c|c|c|c|}
\hline Characteristics & Muvur & Vimtim & Gella & Lamorde & Madanya & Digil \\
\hline 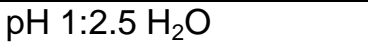 & 6.15 & 5.45 & 5.38 & 4.65 & 6.26 & 5.31 \\
\hline $\mathrm{pH} 1: 2.5 \mathrm{Kcl}$ & 6.27 & 5.72 & 5.76 & 4.69 & 6.06 & 5.60 \\
\hline E.C. $(\mathrm{ds} / \mathrm{m})$ & 0.08 & 0.07 & 0.03 & 0.04 & 0.03 & 0.05 \\
\hline Organic Matter (\%) & 1.48 & 0.69 & 0.82 & 1.90 & 1.08 & 1.30 \\
\hline Total N (\%) & 0.21 & 0.15 & 0.15 & 0.17 & 0.16 & 0.17 \\
\hline Available $\mathrm{P}\left(\mathrm{Cmol} \mathrm{kg}^{-1}\right)$ & 20.83 & 14.33 & 22.65 & 25.88 & 20.15 & 17.68 \\
\hline Exch. $\mathrm{K}\left(\mathrm{Cmol} \mathrm{kg}^{-1}\right)$ & 3.47 & 4.23 & 1.36 & 2.03 & 3.20 & 4.58 \\
\hline $\mathrm{Ca}\left(\mathrm{Cmol} \mathrm{kg}^{-1}\right)$ & 9.54 & 7.55 & 14.82 & 9.03 & 9.76 & 8.17 \\
\hline $\mathrm{Mg}\left(\mathrm{Cmol} \mathrm{kg}{ }^{-1}\right)$ & 12.98 & 6.32 & 4.24 & 0.79 & 8.35 & 3.09 \\
\hline $\mathrm{Na}\left(\mathrm{Cmol} \mathrm{kg}^{-1}\right)$ & 0.94 & 0.96 & 0.37 & 0.98 & 0.98 & 0.83 \\
\hline T.E.B $\left(\mathrm{Cmol} \mathrm{kg}^{-1}\right)$ & 26.89 & 19.04 & 21.46 & 12.82 & 22.27 & 16.66 \\
\hline C.E.C $\left(\mathrm{Cmol} \mathrm{kg}^{-1}\right)$ & 6.86 & 5.72 & 5.24 & 3.18 & 5.53 & 4.18 \\
\hline W.H.C (\%) & 27.73 & 25.51 & 23.16 & 27.44 & 25.17 & 25.59 \\
\hline Bulk Density $\left(\mathrm{g} / \mathrm{cm}^{3}\right)$ & 1.12 & 1.31 & 1.10 & 1.10 & 1.21 & 1.33 \\
\hline Sand (\%) & 63.85 & 67.63 & 78.67 & 66.74 & $60-81$ & 55.71 \\
\hline Silt (\%) & 15.21 & 12.84 & 5.83 & 16.21 & 20.27 & 18.57 \\
\hline Clay (\%) & 15.21 & 19.35 & 15.12 & 17.56 & 18.92 & 25.57 \\
\hline Soil Texture & SL & SL & LS & SCL & $\mathrm{SCL}$ & $\mathrm{SCL}$ \\
\hline
\end{tabular}

Key: $\quad E C=$ Electrical Conductivity

$\mathrm{TEB}=$ Total Exchangeable Bases

$\mathrm{CEC}=$ Cation Exchange Capacity

WHC = Water Holding Capacity

$\mathrm{SCL}=$ Sandy Clay Loam

$\mathrm{SL}=$ Sandy Loam

LS = Loamy Sand 
Appendix 2: Estimation of Volume and Weight of soil loss (Duncan et al. 1978):

i) Volume

Volume of soil loss, $\mathrm{Vsl}_{1}=1 / 6 \pi \mathrm{r}^{2} \mathrm{~h}$

Volume of soil loss, $\mathrm{Vsl}_{2}=1 / 2 \pi \mathrm{l}$

where; $\quad V \mathrm{Vs}_{1}=$ Volume of soil loss at cone shape gully heads

$\mathrm{VsI}_{2}=$ Volume of soil loss along cylinder shape gully length

$\Pi=1.342$, constant of proportion

$r=$ radius of gully head

$\mathrm{R}=$ Radius of gully basin

I = Length of gully basin

$\mathrm{h}=$ perpendicular height of gully head

ii) Weight of soil loss $(\mathrm{Wsl})=\mathrm{Tv}_{1}, \times$ bulk density $\times 0.15 \mathrm{~m} \times 1000 \mathrm{~g}$

iii) Percent soil loss relative to hectare furrow slice percent soil loss $=\mathrm{Wsl} \times 100$.

Where: Tv1, = total volume of soil loss b.d $=$ bulk density $\mathrm{m}=$ metres, $\mathrm{g}=$ gram

iv) Weight of soil loss equivalent to a Tipper load (T56T) $=6160 \mathrm{~kg}$ Equivalent Number of Tipper Load $(\mathrm{TL})=\mathrm{Wsl}(\mathrm{kg}) \div 6160 \mathrm{~kg}$

Appendix 3: Estimation of nutrient elemental loss (Nandwa, 2007):

i) $\quad \mathrm{N}$ Estimates $(\mathrm{kg})=\mathrm{Wsl}(\mathrm{kg}) \times$ analytical $\mathrm{N}(\%) \div 100$

ii) $\quad P$ Estimates $(\mathrm{kg})=\mathrm{Wsl}(\mathrm{kg}) \times$ analytical $\mathrm{P}(\mathrm{ppm}) \div 1,000,000 \mathrm{mg}$

iii) $\quad \mathrm{K}$ Estimates $(\mathrm{kg})=\mathrm{Wsl}(\mathrm{kg}) \times$ analytical $\mathrm{K}\left(\mathrm{Cmol}(+) \mathrm{kg}^{-1}\right) \times 0.39 \mathrm{~g} / \mathrm{kg} \div 1000 \mathrm{~g}$

Where: $\mathrm{Wsl}=$ weight of soil loss

Nutrient loss as per fertilizer bag $(50 \mathrm{~kg})$ equivalents:

i) Nitrogen estimates:

$100 \mathrm{~kg}$ Urea $=46 \% \mathrm{~N}(46 \mathrm{~kg} \mathrm{~N})$

$\mathrm{X} \mathrm{kg}$ Urea $=$ weight of $\mathrm{N}(\mathrm{kg})$ lost

$X \mathrm{~kg}$ Urea $=100 \mathrm{~kg}$ Urea $\times$ weight of $\mathrm{N}(\mathrm{kgO}$ lost $) \div 46 \mathrm{~kg} \mathrm{~N}$

Therefore: Fertilizer bags equivalence $=\mathrm{X} \mathrm{kg}$ urea $\div 50 \mathrm{~kg}$

ii) Phosphorus estimates:

$100 \mathrm{~kg} \mathrm{SSP}=18 \% \mathrm{P}_{2} \mathrm{O}_{5}(18 \mathrm{~kg} \mathrm{P})$

$X \mathrm{~kg}$ SSP $=$ weight of $P(\mathrm{~kg})$ lost $\times 2.29$

$X \mathrm{~kg} \mathrm{SSP}=100 \mathrm{~kg} \mathrm{SSP} \times$ weight of $\mathrm{P}(\mathrm{kg})$ lost $\times 2.29 \div 18 \mathrm{~kg} \mathrm{P}_{2} \mathrm{O}_{5}$

Therefore: Fertilizer bags equivalent $=X \mathrm{~kg} \mathrm{SSP} \div 50 \mathrm{~kg}$

iii) Potassium estimates:

$100 \mathrm{~kg} \mathrm{MOP}=60 \% \mathrm{~K}_{2} \mathrm{O}(60 \mathrm{~kg} \mathrm{~K})$

$X \mathrm{~kg} \mathrm{MOP}=$ weight of $\mathrm{K}(\mathrm{kg})$ lost $\times 1.20$

$X \mathrm{~kg} \mathrm{MOP}=100 \mathrm{~kg} \mathrm{MOP} \times$ weight of $\mathrm{K}(\mathrm{kg})$ lost $\times 1.20 \div 60 \mathrm{~kg} \mathrm{~K} 2 \mathrm{O}$

Therefore: Fertilizer bags equivalent $=X \mathrm{~kg}$ MOP $\div 50 \mathrm{~kg}$

Where: $S S P=$ Single Super Phosphate

MOP $=$ Murate of Potash

2.29 = conversion factor for $\mathrm{P}$ to $\mathrm{P}_{2} \mathrm{O}_{5}$

$1.20=$ conversion factor for $\mathrm{K}$ to $\mathrm{K}_{2} \mathrm{O}$ 